\title{
Establishment of the model on the expression and guidance of contemporary college students' demands in the cyberspace environment
}

\author{
Zhichao Cheng $^{1} \cdot$ Xinyang Liu ${ }^{1}$
}

Received: 27 June 2021 / Accepted: 24 September 2021

(c) The Author(s) 2021

\begin{abstract}
Faced with the most recent changes of the times, expectations of the nation and mission of universities, college students have been playing a major role in their respective university and become increasingly engaged in the development of universities and colleges. They are critical thinkers who are willing to undertake their responsibilities, and they have a strong sense of equality, legal awareness and consciousness for protecting their rights. In addition, in terms of the campus environment where they live, the needs of these college students vary from each other, and their demands for interest deserve much attention from both universities and the entire society. This paper intends to explore the status-quo of how contemporary college students' demands are expressed, guided and handled in the cyberspace environment, and based on our analysis, we aim to put forward targeted suggestions of optimization. We have adopted the method of questionnaire survey to investigate the mechanism on the expression and guidance of contemporary college students' demands in the cyberspace environment. By using such softwares as Excel, SPSS and Amos in our statistical analysis, we have established the model on the expression and guidance of contemporary college students' demands in the cyberspace environment, which provides theoretical support for the endeavor of colleges and universities in this respect.
\end{abstract}

Keywords Contemporary college students' demands $\cdot$ Model of expression and guidance $\cdot$ Cyberspace environment

\section{Questions raised}

Demand is one of the form of expression of human survival and development. Basically, its connotation includes the expression of one's pursuits and needs mainly for the purpose of realizing a certain demand. With the advancement in the era of information technologies, the Internet has become a vital vehicle of communication for college students to interact with university leaders and teachers. In reality, however, cyberspace is a physical environment: it is established by the connectivity of the physical systems and networks, by software regulations and communication protocols. The US is increasingly emphasizing cyberspace as an operating environment. More and more college students will express the interest of themselves or their communities through the online platform. Cyberspace is an international

Xinyang Liu

liuxinyang88@126.com

1 School of Economics and Management, Beihang University, Beijing 100191, China and dynamic environment, characterized by the combined use of electrons and the spectrum of electromagnetic products to generate, store, alter, trade, share, and extract, use, erase information, disrupt physical resources, subject to ongoing changes. Whether the proper demands for interest of college students can be fully expressed, valued and guaranteed by universities will have a direct impact on the development of harmonious campus and the building of world-class universities and first-class disciplines. Give students the chance to speak by asking for opinions on learning experience and material. Do not wait till the finish of your course to learn about the changes on the way. For example, you might imagine that kids will like projects in groups, but you will find out that they fear the idea.

\section{Contradiction between the strong demands for interest and the traditional educational philosophy}

Faced with the recent changes of the times, the novel expectations of the nation and the new mission of universities, college

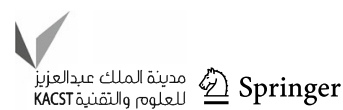


students have been playing a major role in their respective university and become increasingly engaged in the development of universities and colleges. The cornerstone to this learning technique is active participation. Students can freely explore their own thoughts and untraditionally communicate concepts. They are both thoughtful and responsible, while having a strong sense of equality, legal awareness and consciousness for protecting their rights. In addition, in terms of the campus environment where they live, these college students have varying needs, and their demands for interest deserve much attention from both universities and the entire society. Actually, the number of people enrolled in the education system. Possible education demand can be defined as the entire number of people willing to pay for their education. However, the traditional concept of educational management which holds that "universities are decisionmakers, whereas students are followers and practitioners" is still deeply rooted, which greatly suppresses the vitality and enthusiasm of young students to express their demands. Here, we focus primarily on the four key philosophy types which might enable you to construct and compose your doctrinal statement-permanence, essentiality, romanticism and progressiveness.

\section{Contradiction between multiple demands for interest and limited channels of expression}

At present, college students' demands for interest have shown new characteristics while becoming more diversified and differentiated with numerous types. My opinion is that all children are unique and need an educational environment that stimulates their physical, mental, emotive and social growth. I want to establish such an atmosphere where kids can realise their full potential. In addition, given that college students' demands are not only related to one single department of management, it is necessary to coordinate multiple departments cope with such demands. The demand for education derived from individuals' wants and aspirations is social demand in contrast to the desire for education based on social needs. Social demand is the combined consequence of individual choices in conditions of educational choice. If universities only resort to a couple of platforms or channels, it is impossible for them to meet the needs of college students on the channels of speaking up for their interest. It is a common practice that the administrative channel is the only or the major way for students to express their demands for interest in the university. However, when the administrative channel is blocked and other channels are absent, college students will be hindered from expressing their demands for interest, which is more likely to cause conflicts and affect the establishment of a harmonious campus. It enables people to become better citizens, acquire a better career, it illustrates how good is different from bad. Education demonstrates the significance of hard effort and helps us to grow and develop at the same time. We are thus able, through knowing and respecting the rights, laws and regulations, to form a better society.

\section{Contradiction between the handling of the demands for interest and the absence of the mechanism on demand guidance}

An increasing number of college students opt for informal online channels such as BBS, WeChat Moments, Zhihu to express their demands. You will not be expected to travel unlike traditional internships, and can be working from anywhere in the world, saving money on rent and travel expenses. Improve the CV: working from home will increase your time and self-discipline as you gain experience in your job. However, universities generally do not pay much attention to the demands raised in informal online platforms, and worse still, there is no supporting mechanisms on the handling and guidance of the demands raised in the informal online channels. A global realm of IT networks comprised of a network of IT infrastructures such as the internet, telecoms networks, computer system and integrated processors and controllers. While resorting to informal online channels, some students may excessively claim their interest and raise their demands. As a result, the Internet risks becoming a place for students to vent their anger and emotion, and may even lead to severe negative impact on the public opinions and undermine the public images of universities. The Internet environment is the definition of cyberspace. The home of Google, Yahoo and Facebook is an example of cyberspace. The electronic media for the electronic communication of the computer networks. The virtual space produced through interconnected computers and internet computer networks.

At present, in terms of the aforementioned issues, the scholars both at home and abroad have proposed to establish the mechanism on the expression and guidance of students' demands. In addition, they have studied how students could improve ways of expressing their demands so as to have such demands met in a more effective manner. The people can communicate, exchange ideas, share information, support socially, run business, direct actions, build artistic media, play games, engage in political discussions, and so on using this worldwide network as a social experience. Sometimes they are known as cybernauts. Researchers have, however, so far there is not an objective, systematic and scientific view on how the management of the university could better guide students in the expression of their demands. The main reason lies in the lack of a clear theoretical framework and scientific research methodology. As a result, current studies have limitations in terms of the applicable scope and reference significance, thus failing to provide an optimal response to the aforementioned issues. Social media can contribute to 
centralising the collective knowledge of a whole class to make learning and communication easier for all. Initiate a contact list or class group with advice for studying and sharing. Invite social media professors to follow or join discussions in a group discussion. In this paper, we have set up the model on the expression and guidance of contemporary college students' demands in the cyberspace environment. We attempt to cope with the issues stated above and we intend to explore the channels as well as the relationship between the expression and guidance of students' demands with the governance capabilities of the university, the ability of students in their expression of demands, and the students' satisfaction about the handling of their demands. It was found therefore that the students' sociability scores vary considerably according to the frequency of their use in Youtube, Instagram and WhatsApp, but not according to the frequency of their use on Facebook.

\section{Empirical analysis with descriptive statistics}

Based on the principle hypothesis and the status-quo of contemporary college students' expression of demands in the cyberspace environment, we have formulated relevant questionnaires and scales. In every student's life, social media play a vital role. Access to knowledge, information and communication via social media is sometimes easier and easier. Tutors and students can be connected and benefit from the learning and teaching of one other by using these platforms. The questionnaire is divided into 11 parts, including students' skills of communication and expression, psychological capital, type of demands, establishment of platforms for the raising of demands, level of service and management of the university, response to the content of demands, response to the attitude of demands, level of satisfaction about the handling of demands, improvement of students' expression ability and management level of the university, in addition to personal information. We have distributed 550 questionnaires in total and received 502 valid responses. The effective rate amounts to $91.3 \%$. Today's learners are looking for a learning environment not as outmoded as conventional, but specifically designed to encourage thought. They like the learning environment that enhances their ability to learn through change of teaching tactics. They want to participate in an effective learning environment that delivers a sense of success and can be adaptive and engaged with fellow students and educators.

\section{Basic information of interviewees}

As shown in Table 1, there are 173 male respondents, which accounts for $34.5 \%$ of the total sample; and there are 329 female respondents, which accounts for $65.5 \%$ of the total sample. In the sample group investigated, more female college students raise demands online than men. In contrast with undergraduate students, nearly half of the graduate students raise their demands online. An efficient learning environment is a location where you are not accepted for what you do. This is where both your struggle and your successes can be honest and in both situations open-minded and curious. Social, physical, psychological or cultural elements typically affect the learning capacities of the learners deeply. If the learning environment does not lead to new knowledge or skills, it will be difficult for students to remain integrated or interested. In terms of the types of schools, most of the respondents who raise their demands online come from national key universities included in the Project 985 and Project 211, accounting for $47 \%$ of the total, followed by ordinary first-tier universities, accounting for $31.5 \%$. What comes third is the second-tier universities, accounting for $15.1 \%$ of the total, whereas the third-tier universities account for a relatively low proportion. As for the background of the students' majors, among the three type of majors (technology, natural science and liberal art), there is a relatively equivalent proportion of the students who express their demands online, namely, about $30 \%$ of the respondents for each major. Current learning environments have been developed in a digital age to satisfy the needs of students. Contemporary learning rooms give flexibility and collaboration chances, independence and global resources connectivity.

There are four different types of learning contexts that each have their own elements. Learning environments may be student- or learner-focused; knowledge-based; appraisalbased; and community-based. In terms of student leaders, $69.1 \%$ of the respondents once held leading positions as students during their studying and $30.9 \%$ of them had no such experiences. In other words, college students who once served as student leaders are more likely to express their demands through the online channels. In terms of internship, students with internship experience are more likely to express their demands online, accounting for $77.1 \%$ among the surveyed students. In terms of academic performance, the proportion of students who express their demands online decreases in accordance with their GPA ranking, which is 40 $2 \%, 36.1 \%$ and $19.1 \%$, respectively.

\section{Status-quo of demands}

In the cyberspace environment, we have explored the status-quo of contemporary college students' expression of demands by carrying out research from such aspects as the type of demands, platform of expressing demands, mode of communicating demands and reasons for raising demands. In addition, we have also analyzed the survey results from the perspective of the response to demands and results of the demand handling. 
Table 1 Basic information of interviewees

\begin{tabular}{|c|c|c|}
\hline Statistical variable & Frequency & Percentage \\
\hline \multicolumn{3}{|l|}{ Gender } \\
\hline Male & 173 & 34.5 \\
\hline Female & 329 & 65.5 \\
\hline \multicolumn{3}{|l|}{ Age } \\
\hline 1 & 18 & 3.6 \\
\hline 2 & 391 & 77.9 \\
\hline 3 & 87 & 17.3 \\
\hline 4 & 4 & 0.8 \\
\hline 5 & 2 & 0.4 \\
\hline \multicolumn{3}{|l|}{ Grade } \\
\hline Freshman & 19 & 3.8 \\
\hline Sophomore & 31 & 6.2 \\
\hline Junior & 61 & 12.2 \\
\hline Senior & 82 & 16.3 \\
\hline Master candidate & 257 & 51.2 \\
\hline Doctoral candidate & 24 & 4.8 \\
\hline Other & 28 & 5.6 \\
\hline \multicolumn{3}{|l|}{ College type } \\
\hline $985 \& 211$ colleges and universities & 236 & 47 \\
\hline Ordinary first-tier universities & 158 & 31.5 \\
\hline Second-tier universities & 76 & 15.1 \\
\hline Third-tier universities & 10 & 2 \\
\hline Other & 22 & 4.4 \\
\hline \multicolumn{3}{|l|}{ Professional } \\
\hline Science & 154 & 30.7 \\
\hline Engineering & 152 & 30.3 \\
\hline Liberal-art & 152 & 30.3 \\
\hline Arts & 16 & 3.2 \\
\hline Other & 28 & 5.6 \\
\hline \multicolumn{3}{|l|}{ Whether to serve as student cadre } \\
\hline Yes & 347 & 69.1 \\
\hline \multicolumn{3}{|l|}{ During the period of college } \\
\hline No & 155 & 30.9 \\
\hline \multicolumn{3}{|l|}{ Whether have internship experience } \\
\hline Yes & 387 & 77.1 \\
\hline No & 115 & 22.9 \\
\hline \multicolumn{3}{|l|}{ Study result } \\
\hline The top $20 \%$ & 202 & 40.2 \\
\hline $20-40 \%$ & 181 & 36.1 \\
\hline $41-60 \%$ & 96 & 19.1 \\
\hline $61-75 \%$ & 12 & 2.4 \\
\hline After $25 \%$ & 2 & 0.4 \\
\hline
\end{tabular}

\section{Type of demands}

First, in terms of the type of demands expressed by contemporary college students in the cyberspace environment, the
Table 2 Type of demands

\begin{tabular}{lrrr}
\hline & \multicolumn{2}{l}{ Response } & \multirow{2}{*}{ Percentage of cases } \\
\cline { 2 - 3 } & $N$ & Percentage & \\
\hline A. Daily life & 380 & 33.4 & 75.7 \\
B. Management & 216 & 19.0 & 43.0 \\
$\quad$ service & & & \\
C. Academic burden & 178 & 15.7 & 35.5 \\
D. Interpersonal & 88 & 7.7 & 17.5 \\
$\quad$ relationships & & & \\
E. Policy suggestions & 86 & 7.6 & 17.1 \\
F. Material interests & 99 & 8.7 & 19.7 \\
G. Spiritual demand & 50 & 4.4 & 10.0 \\
H. Special problems & 31 & 2.7 & 6.2 \\
I. Other & 9 & 0.8 & 1.8 \\
Total & 1137 & 100.0 & 226.5 \\
\hline This table is prepared & & &
\end{tabular}

This table is prepared when the dichotomy group value is set as one

survey shows that daily life accounts for the highest proportion. Specifically, the issues closely related to daily life such as dormitory maintenance and canteen meals account for $75.7 \%$ among all cases. About three quarters of the college students who have expressed their demands online have raised issues related to daily life. The second most raised issues are related to management service. For instance, $43.0 \%$ of the compliant cases are related to the complicated procedures and low efficiency of services of the university's administrative departments. Academic workloads rank third among all the issues raised, including complaints and suggestions on examination, homework and curriculum setting, and this part accounts for $35.5 \%$ of the total. The fourth is material rights and interests, including the disputes related to the allocation of grants, awards and honors, accounting for $19.7 \%$. In addition, the demands expressed by students primarily through the Internet comprise those issues related to interpersonal relationship, which mainly includes the conflicts between mentors and students, and conflicts between roommates, accounting for $17.5 \%$ of the total, whereas policy suggestions related to the planning of school buildings and fitness venues account for $17.1 \%$ among all the demands expressed.

The proportion of specific types of demands is shown in Table 2. With the development of the Internet technologies, college students have gradually become reliant on the online channels in expressing their demands, and such expression has become increasingly related to and consistent with the real-life behavior of students. In addition, the main subjects of the students' demand expression through the Internet are closely related to the real life of college students in general. The main content of their demand is the daily life such as dormitories, canteens, school management and academic situation. 


\section{Platform of expressing demands}

In terms of the platform built by the university for expressing demands, students mainly raise demands through the school's social network accounts (Micro-blog account or WeChat official account) and the school's official website, accounting for $56.8 \%$ and $51.8 \%$, respectively. The second choices for college students to raise demands online include the principal's mail boxes, the university's BBS (i.e., the school's online forums) and WeChat Moments, accounting for 26.3\%, 26.3\% and $25.1 \%$, respectively. Some students will also resort to such platforms for expressing their demands, such as WeChat Group, Tieba, Douban, Micro-blog and other online public forums, accounting for $19.9 \%$ and $19.3 \%$ respectively.

As shown in Table 3, the platform for college students to express their demands are typically non-standard, private and flat. Oftentimes, students will directly resort to social media platforms to report issues across administrative levels. In this way, students can directly communicate with the school leadership, but such method still lacks effectiveness and efficiency. Redundant issues may be reported, leading to improper discussions or deliberations that deviate from students' concerns. Consequently, the originally reported issues might not be tackled in practice, which hinders the university's leadership from handling the relevant issues. This will lead to the instability factors, and in the meantime, it will have a negative impact on the development of both the university and college students. Therefore, it is necessary to develop a more effective and practical platform for students to express their demands. The ideal platform shall differ from the traditional channels of collecting demands, such as telephone, email and mailbox. The platform that allows for anonymous claims and attracts the gathering of peers is regarded as more humane. In addition, the integration of the ideological and political education of college students helps foster a stable campus and ensure that the information is disseminated symmetrically.

\section{Mode of communication and reasons behind demands}

Communication network refers to the channel of information transmission arisen from the communication in group organizations [1]. Keith Davis, an American psychologist, put forward in his research that there are four ways of communication during information transmission and communication exterior to the formal organizational system, namely, cluster grapevine, gossip grapevine, probability grapevine and single strand grapevine. Specifically, cluster grapevine refers to the fact that there may be several key figures during communication, who can pass on the information to some other people [2]. This mode of communication features certain flexibility during communication and expression. The gossip grapevine refers a process of communication that has unique
Table 3 Platform of expressing demands

\begin{tabular}{|c|c|c|c|}
\hline & \multicolumn{2}{|c|}{ Response } & \multirow[t]{2}{*}{ Percentage of cases } \\
\hline & $N$ & Percentage & \\
\hline $\begin{array}{l}\text { A. College's official } \\
\text { website }\end{array}$ & 260 & 20.9 & 51.8 \\
\hline $\begin{array}{l}\text { B. College's } \\
\text { microblog or } \\
\text { WeChat official } \\
\text { account }\end{array}$ & 285 & 22.9 & 56.8 \\
\hline $\begin{array}{l}\text { C. College leaders } \\
\text { reception day and } \\
\text { other offline forms }\end{array}$ & 75 & 6.0 & 14.9 \\
\hline $\begin{array}{l}\text { D. The principal } \\
\text { mailbox }\end{array}$ & 132 & 10.6 & 26.3 \\
\hline $\begin{array}{l}\text { E. Campus BBS or } \\
\text { campus forum }\end{array}$ & 132 & 10.6 & 26.3 \\
\hline F. Circle of friends & 126 & 10.1 & 25.1 \\
\hline G. WeChat group & 100 & 8.0 & 19.9 \\
\hline $\begin{array}{l}\text { H. Online public } \\
\text { forums such as } \\
\text { Tieba, microblog } \\
\text { and Douban }\end{array}$ & 97 & 7.8 & 19.3 \\
\hline I. Other & 36 & 2.9 & 7.2 \\
\hline Total & 1243 & 100.0 & 247.6 \\
\hline
\end{tabular}

This table is prepared when the dichotomy group value is set as one

characteristic, in which one person informs everyone else. The communication process of probability grapevine is that the information disseminators can pass on the information to whoever meet them without a certain key figure or any selectivity [3]. The communication process of single strand grapevine is that one person passes on the information to another person, and this person only carries on to tell the next person, which is the rarest situation.

In terms of the ways of communication, as shown in Table 4, college students who express their demands through the online channels are more likely to consent that a couple of selected people will convey their demands to several other people. In other words, they have adopted the communication mode of cluster grapevine, which can also be understood as jointly submitting letters in the popular sense. In terms of the way of communication, the cluster grapevine is generally considered to be the fastest and the most diffusive channel. The statistical results have shown that college students have gradually reduced the adoption of the communication modes of single strand grapevine, gossip grapevine and probability grapevine. In other words, college students select their way of expressing demands in a rather purposeful manner [4]. They hope to inform more people of their own demands so as to address the issues in a more efficient manner. This research finding is also reflected in the reasons behind students' use of the Internet to express demands. Students generally believe that through the online expression of demands, they can

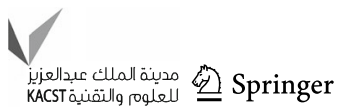


Table 4 Mode of demand expression and reasons behind

\begin{tabular}{|c|c|c|c|c|c|}
\hline & Digital & Minimum value $(M)$ & Maximum value $(X)$ & Average $(E)$ & Standard deviation \\
\hline $\begin{array}{l}\text { When demand is put forward, a specific group of } \\
\text { people relay the demand to others }\end{array}$ & 502 & 1 & 5 & 3.61 & 0.972 \\
\hline I demand to all the others on my own & 502 & 1 & 5 & 2.83 & 1.072 \\
\hline $\begin{array}{l}\text { It doesn't matter who you say it to when you make a } \\
\text { demand, it doesn't matter who accepts it }\end{array}$ & 502 & 1 & 5 & 2.77 & 1.103 \\
\hline I tell a specific person about the demand by myself & 502 & 1 & 5 & 3.18 & 1.036 \\
\hline $\begin{array}{l}\text { Through online demand, I can let more people know } \\
\text { my demand }\end{array}$ & 502 & 1 & 5 & 3.86 & 0.922 \\
\hline I think online demands can Let off steam & 502 & 1 & 5 & 3.23 & 1.109 \\
\hline $\begin{array}{l}\text { I think online demands can help me solve problems } \\
\text { more efficiently }\end{array}$ & 502 & 1 & 5 & 3.80 & 0.971 \\
\hline I hope to alert/warn others through online demands & 502 & 1 & 5 & 3.78 & 1.040 \\
\hline
\end{tabular}

Table 5 Guidance of demands and results of the demand handling

\begin{tabular}{|c|c|c|c|c|c|c|}
\hline & \multirow{2}{*}{$\begin{array}{l}\text { Average }(E) \\
\text { Statistic }\end{array}$} & \multirow{2}{*}{$\begin{array}{l}\text { Standard deviation } \\
\text { Statistic }\end{array}$} & \multicolumn{2}{|c|}{ Partial degrees } & \multicolumn{2}{|l|}{ Kurtosis } \\
\hline & & & Statistic & Standard error & Statistic & Standard error \\
\hline Demand content response & 3.54 & 0.78 & -0.568 & 0.109 & 0.804 & 0.218 \\
\hline Demand attitude response & 3.56 & 0.85 & -0.633 & 0.109 & 0.586 & 0.218 \\
\hline Demand response & 3.56 & 0.75 & -0.822 & 0.109 & 1.373 & 0.218 \\
\hline Efficient service management level & 3.59 & 0.67 & -0.58 & 0.109 & 0.429 & 0.218 \\
\hline Results-demand processing satisfaction & 3.58 & 0.84 & -0.728 & 0.109 & 0.702 & 0.218 \\
\hline Results-students' expressive ability & 3.58 & 0.74 & -0.398 & 0.109 & 0.695 & 0.218 \\
\hline Results-university management ability & 3.61 & 0.79 & -0.512 & 0.109 & 0.556 & 0.218 \\
\hline Overall result of demand & 3.59 & 0.66 & -0.616 & 0.109 & 0.879 & 0.218 \\
\hline
\end{tabular}

inform more people of their personal demands so as to tackle the issues more efficiently [5]. In the meantime, they can remind or even warn others of the problems rather than simply venting out their emotion.

\section{Response to the demands and results of the demand handling}

In terms of the response to demands, we have conducted research from two aspects, namely, response to the content of demands and response to the attitude of demands. The results have shown that the university's response to the demands expressed by college students (such as addressing the main issues claimed by students and focusing on the subjects of the problems reported by students) in the cyberspace environment is relatively proactive. In addition, the university attaches great importance to pacifying and caring for the emotion, mentality and attitude of students when responding to their demands [6]. Therefore, the university reaches the above average level both in terms of the response to the content and the response to the attitude. In the meantime, the results of the demand handling are relatively recognized by college students, which is at the above average level [7]. As for the other results of the expression of demands, students believe that the online expression of demands can improve their expression ability on the one hand, and can also improve the management capabilities of universities on the other hand [8]. The specific mean value and distribution are shown in Table 5. The results of skewness and kurtosis have shown that the variables are basically in normal distribution, which conforms to the general law of data distribution.

\section{Analysis of reliability and validity}

\section{Reliability test}

In this paper, we have used the software of SPSS 22.0 to calculate the Cronbach's $\alpha$ (Cronbach) coefficient and examined the consistency of the subjects' response to the items in the scale. We have conducted the Cronbach's alpha reliability test conducted on the questionnaire, and the statistical results are shown in Table 6 . The Cronbach's $\alpha$ coefficient of demand response amounts to 0.889 , the results of the demand handling amounts to 0.886 and the university's level of service management amounts to 0.949 . In addition, the 
Table 6 Reliability analysis

\begin{tabular}{lcl}
\hline Category & Number & $\alpha$ coefficients \\
\hline Demand response & 8 & 0.889 \\
Demand results & 10 & 0.886 \\
University management ability & 19 & 0.949 \\
Students' expressive ability & 10 & 0.741 \\
Psychological capital & 12 & 0.904 \\
teacher communication & 10 & 0.871 \\
\hline
\end{tabular}

Table $7 \mathrm{KMO}$ and Bartlett's test

\begin{tabular}{lll}
\hline KMO & 0.906 & \\
Bartlett's spherical test & $\begin{array}{l}\text { The approximate } \\
\text { chi-square } \\
\text { Degrees of freedom } \\
\text { significant }\end{array}$ & 28 \\
& & 0.000 \\
\hline
\end{tabular}

Cronbach's $\alpha$ coefficient of students' initial communication and expression skills amounts to 0.741 and that of psychological capital amounts to 0.904 and that of communication with teachers amounts to 0.871 . The $\alpha$ values of all scales and their subscales exceeded 0.7 , which are consistent with the requirements. The internal consistency of the scale is good, and the internal consistency of the research is relatively high, indicating that the reliability of the questionnaire is optimal.

\section{Validity test}

\section{Exploratory factor analysis}

First, we have used KMO and Bartlett's sphere tests to examine the structural validity of the questionnaire. The results of the KMO analysis of the scale are shown in Table 7, and the $\mathrm{KMO}$ value amounts to 0.906 . The Bartley's spherical test is significant, which features good structural validity and meets the conditions of factor analysis.

We have used the software SPSS 22.0 for exploratory factor analysis of the scale and we have adopted the method of the Kaiser standardized orthogonal rotation. The results are shown in Table 8. From the aspect of the response to demands, we have extracted two factors, and the factor load degree of all subjects reaches above 0.6 , indicating that the validity of the questionnaire is optimal.

Second, we have examined the validity of the questionnaire via the KMO and the Bartlett's methods. The results of the KMO analysis of the scale are shown in Table 9, and the KMO value amounts to 0.890 . The Bartley's spherical test is significant, which features optimal structural validity and meets the conditions of factor analysis.

We have used the software SPSS 22.0 to conduct the exploratory factor analysis of the scale and we have used
Table 8 Rotated component matrix of demand response

\begin{tabular}{|c|c|c|}
\hline & \multicolumn{2}{|c|}{ Component } \\
\hline & 1 & 2 \\
\hline $\begin{array}{l}\text { The relevant leadership of the college/university } \\
\text { respond to my demand }\end{array}$ & 0.429 & 0.615 \\
\hline The counselor responds to my demand & 0.137 & 0.909 \\
\hline $\begin{array}{l}\text { People related to the content of the demands } \\
\text { respond to me }\end{array}$ & 0.208 & 0.740 \\
\hline $\begin{array}{l}\text { The college made a targeted response to the content } \\
\text { of my demand }\end{array}$ & 0.364 & 0.640 \\
\hline $\begin{array}{l}\text { In terms of solving the problem, I'm satisfied with } \\
\text { response to the demand }\end{array}$ & 0.749 & 0.360 \\
\hline My demand was responded timely & 0.693 & 0.473 \\
\hline $\begin{array}{l}\text { The college's response to the demand is very } \\
\text { profession }\end{array}$ & 0.815 & 0.224 \\
\hline The college's response to the demand is very kind & 0.843 & 0.135 \\
\hline
\end{tabular}

Extraction method: principal component analysis

Rotation method: method of the Kaiser standardized maximum variance The rotation converges after three iterations

Table 9 KMO and Bartlett's tests

\begin{tabular}{lll}
\hline KMO & 0.890 & \\
Bartlett's spherical test & $\begin{array}{l}\text { The approximate } \\
\text { chi-square }\end{array}$ & 2375.930 \\
& $\begin{array}{l}\text { Degrees of freedom } \\
\text { significant }\end{array}$ & 45 \\
& & 0.000 \\
\hline
\end{tabular}

the method of the Kaiser standardized orthogonal rotation. The results are shown in Table 10.

From the aspect of the results of demand handling, we have extracted three factors, and the factor load degree of all subjects reaches above 0.6 , indicating that the validity of the questionnaire is optimal.

In terms of the mode of communication, we have used the KMO and Bartlett's sphere tests to examine the structural validity of the questionnaire. The results of the KMO analysis of the scale are shown in Table 11, and the KMO value amounts to 0.819 . The Bartley's spherical test is significant, which features optimal structural validity and meets the conditions of factor analysis.

We have used the software SPSS 22.0 to conduct exploratory factor analysis of the scale, and we have used the method of the Kaiser standardized orthogonal rotation. The results are shown in Table 12.

All the above factors have shown that in terms of the two factors that we have extracted from the mode of communication of students, the factor load of all subjects reaches above 0.6 , indicating that the validity of the questionnaire is optimal in measuring the mode of communication of students.

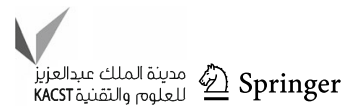


Table 10 Rotated component matrix

\begin{tabular}{|c|c|c|c|c|}
\hline & & \multicolumn{3}{|c|}{ Component } \\
\hline & & 1 & 2 & 3 \\
\hline \multicolumn{2}{|c|}{$\begin{array}{l}\text { I'm quite satisfied with the way of demand } \\
\text { was handled }\end{array}$} & 0.779 & 0.307 & 0.161 \\
\hline \multicolumn{2}{|c|}{$\begin{array}{l}\text { I'm quite satisfied with the results of } \\
\text { demand was handled }\end{array}$} & 0.847 & 0.216 & 0.146 \\
\hline \multicolumn{2}{|c|}{ The problem I demand for was well solved } & 0.808 & 0.204 & 0.270 \\
\hline \multicolumn{2}{|l|}{ I was soothed } & 0.809 & 0.082 & 0.194 \\
\hline \multicolumn{2}{|c|}{$\begin{array}{l}\text { Through demand expression, my language } \\
\text { expression ability has been improved }\end{array}$} & 0.155 & 0.305 & 0.701 \\
\hline \multicolumn{2}{|c|}{$\begin{array}{l}\text { Through demand expression, my } \\
\text { interpersonal relationship and } \\
\text { communication become more harmonious }\end{array}$} & 0.213 & 0.141 & 0.846 \\
\hline \multicolumn{2}{|c|}{$\begin{array}{l}\text { Through demand expression, I think I have } \\
\text { ability to solve more problems }\end{array}$} & 0.259 & 0.309 & 0.689 \\
\hline \multicolumn{2}{|c|}{$\begin{array}{l}\text { By dealing with my demand, the } \\
\text { management ability of the college has been } \\
\text { improved }\end{array}$} & 0.227 & 0.819 & 0.153 \\
\hline \multicolumn{2}{|c|}{$\begin{array}{l}\text { By dealing with my demands, the campus } \\
\text { atmosphere became better }\end{array}$} & 0.217 & 0.796 & 0.277 \\
\hline \multicolumn{2}{|c|}{$\begin{array}{l}\text { On the whole, my demand is conducive to } \\
\text { the future development of the college }\end{array}$} & 0.178 & 0.689 & 0.324 \\
\hline \multicolumn{5}{|c|}{$\begin{array}{l}\text { Extraction method: principal component analysis } \\
\text { Rotation method: method of Kaiser standardized maximum variance } \\
\text { The rotation converges after } 4 \text { iterations }\end{array}$} \\
\hline \multicolumn{5}{|c|}{ Table $11 \mathrm{KMO}$ and Bartlett's tests } \\
\hline \multicolumn{5}{|l|}{ KMO } \\
\hline \multirow[t]{3}{*}{ Bartlett's spherical test } & $\begin{array}{l}\text { The approximate } \\
\text { chi-square }\end{array}$ & & \multicolumn{2}{|c|}{2409.542} \\
\hline & Degrees of freedo & & \multicolumn{2}{|c|}{45} \\
\hline & significant & & \multicolumn{2}{|c|}{0.000} \\
\hline
\end{tabular}

\section{Confirmatory factor analysis}

We have used the confirmatory factor analysis to examine the aggregate validity, discriminative validity and common method deviation (CMV) of the identified dimensions and structures. Therefore, we have conducted the confirmatory factor analysis on the three dimensions of the demand guidance for intermediary variables (namely, the university's service management, response to the content of demands and response to the attitude of demands), and three dimensions of the demand handling for dependent variables (namely, satisfaction about the handling of demands, students' expression ability and the university's management capabilities).

Guidance of demands The results in Table 13 have shown that there is a significant correlation between all items and the measured item factors $(P<0.001)$, indicating that there is a high level of validity of the subjects of items. The nor-
Table 12 Rotated component matrix

\begin{tabular}{|c|c|c|}
\hline & \multicolumn{2}{|c|}{ Component } \\
\hline & 1 & 2 \\
\hline My language skills are very good & 0.775 & 0.010 \\
\hline $\begin{array}{l}\text { I think clearly when I communicate with } \\
\text { people }\end{array}$ & 0.826 & -0.107 \\
\hline $\begin{array}{l}\text { I was able to highlight how things started, how } \\
\text { they ended }\end{array}$ & 0.791 & -0.009 \\
\hline My expression is fluent & 0.796 & -0.058 \\
\hline I prefer bring good news but not bad & 0.522 & 0.206 \\
\hline I often look on the bright side of things & 0.661 & -0.105 \\
\hline $\begin{array}{l}\text { I can often communicate happily with most } \\
\text { people }\end{array}$ & 0.785 & -0.081 \\
\hline $\begin{array}{l}\text { I often misunderstand others during } \\
\text { communication, in hindsight found out I was } \\
\text { wrong }\end{array}$ & -0.014 & 0.866 \\
\hline Communicating with me can be stressful & -0.002 & 0.905 \\
\hline $\begin{array}{l}\text { I often complain when communicating with } \\
\text { others }\end{array}$ & -0.084 & 0.898 \\
\hline
\end{tabular}

malized load factor is about 0.7 , indicating a strong level of correlation. The results of the convergence validity test have shown that the standardized factors of all the items are consistent with each other, which are all above 0.6 and reach the test value. The results have shown that each measured item has a robust capability in explaining the potential variables. In addition, the reliability of the combination of latent variables reaches 0.7 , indicating that each group of measured items has a high level of internal consistency. The AVE values all meet the standard of more than 0.5 , indicating that the measured items can reflect the characteristics of latent variables. In conclusion, the measurement model has optimal validity of convergence. Therefore, the results of the confirmatory factor analysis also support the three-dimensional division of demand guidance, which can be measured from three aspects, namely, response to the content of demands, response to the attitude of demands and the university's service management level.

The results of discriminant validity test are shown in Table 14. The square root values of the average extraction variance on the diagonal exceeds the corresponding correlation coefficient, indicating that the scale has optimal discriminant validity.

Results of demand handling The results specified in Table 15 have shown that there is a significant correlation between all items and the factors of the measured items $(P<0.001)$, indicating that there is a high level of validity of the subjects of items. The results of the convergence validity test have 


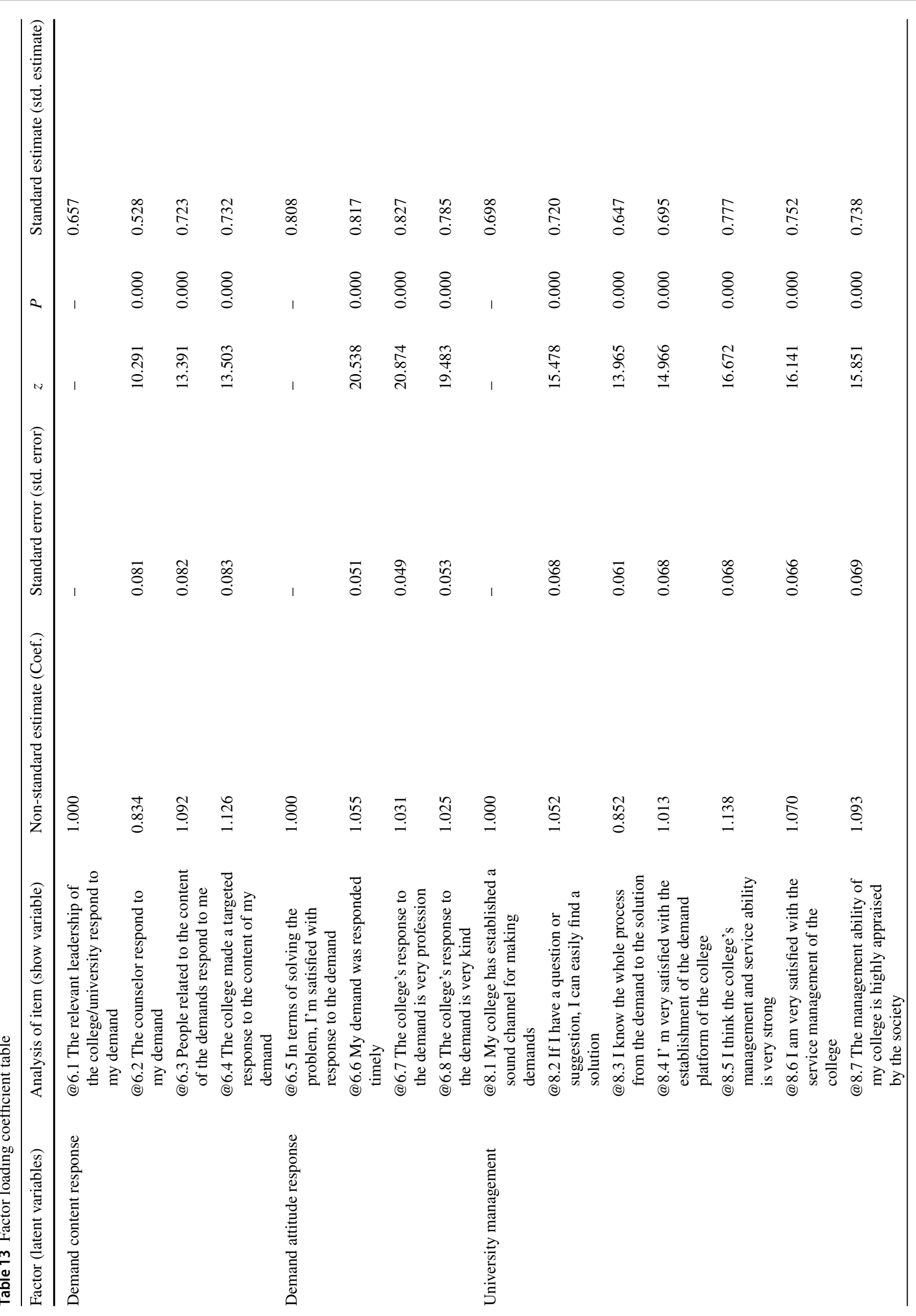




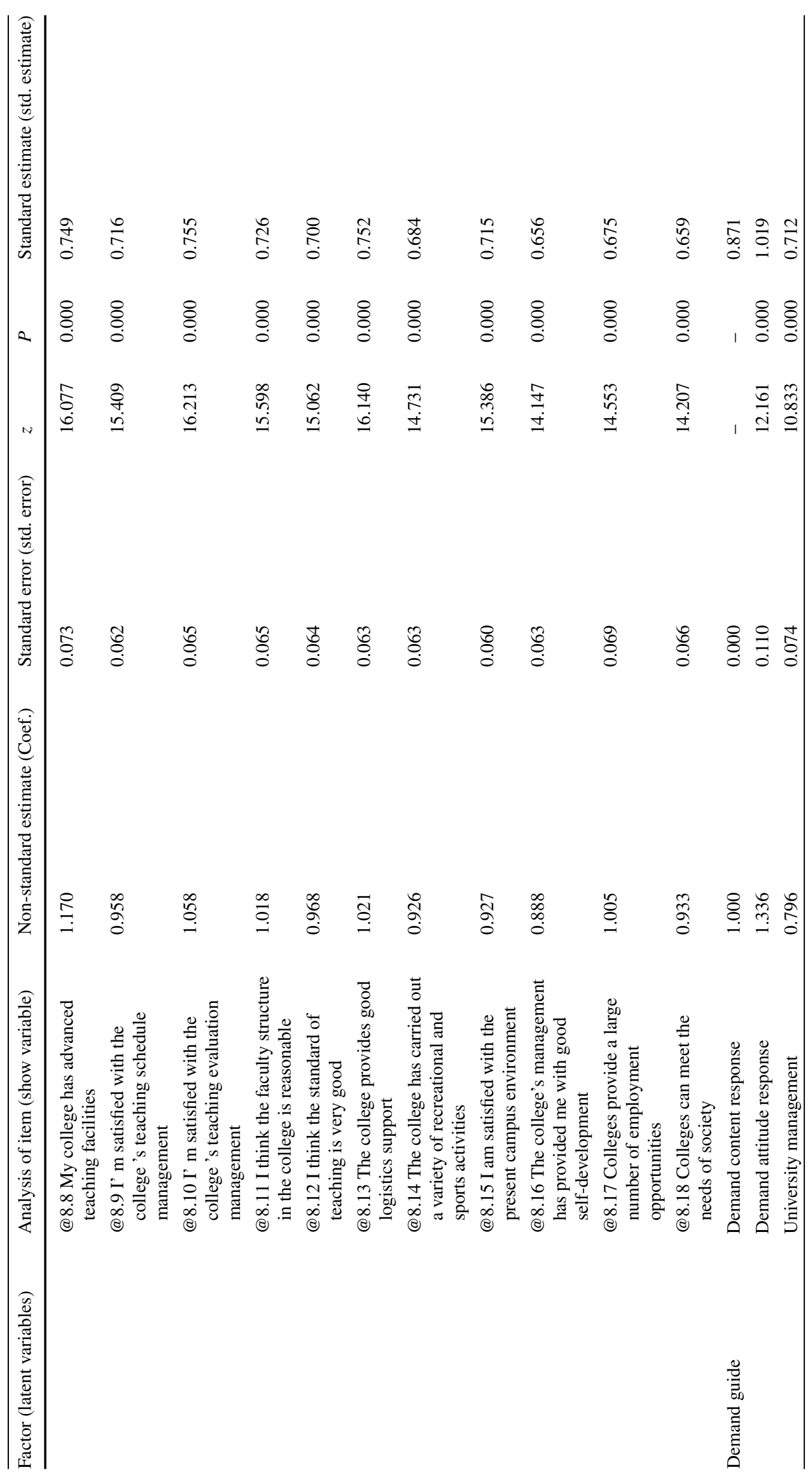


Table 14 Discriminant validity: Pearson correlation and AVE square root values

\begin{tabular}{llll}
\hline & $\begin{array}{l}\text { Demand content } \\
\text { response }\end{array}$ & $\begin{array}{l}\text { Demand attitude } \\
\text { response }\end{array}$ & University management \\
\hline $\begin{array}{l}\text { Demand content } \\
\text { response }\end{array}$ & 0.663 & & \\
$\begin{array}{c}\text { Demand attitude } \\
\text { response }\end{array}$ & 0.733 & 0.809 & 0.714 \\
University management & 0.527 & 0.666 & \\
\hline
\end{tabular}

The diagonal numbers are the square root values of AVE shown that the standardized factors of all the items are consistent with each other, which is above 0.6 and reaches the test value. The results have shown that each measured item has a strong capability in explaining the latent variables.

In the meantime, the results in Table 16 have shown that the reliability of the combination of latent variables amounts to 0.7 , indicating that the measured items of each group have a high level of internal consistency. The AVE values all meet the standard of more than 0.5 , indicating that the measured items can reflect the characteristics of latent variables.

In conclusion, the measurement model has a relatively good convergence validity. Therefore, the results of the confirmatory factor analysis also support the three-dimensional division of the results of demand handling, which can be measured from three aspects, namely, the satisfaction about the handling of demands, improvement of students' expression ability and enhancement of the university's management capabilities.

In Table 17, we have analyzed the discriminant validity. Judging from the results of our analysis, the minimum square root value of AVE corresponding to three factors amounts to 0.716 , which exceeds the maximum value of the correlation coefficient between factors that amounts to 0.604 . In conclusion, the research data has a relatively good discriminant validity.

To sum up, in the structural equation model, we can regard the university's service management, response to the content of demands and response to the attitude of demands as intermediary variables, and we can take the satisfaction about the handling of demands, students' expression ability and the university's management capabilities as three dimensions to measure the dependent variables of the handling of demands.

\section{Model building}

\section{Overall model}

Judging from the results of the validity test, all item factor loads of the measurement model can meet the validity standard. Therefore, the entire model of the structural equation is set up based on the measurement model. There are three latent variables in the model, namely, expression of demands, guidance of demands and results of demand handling. We have used 19 observation variables to indirectly measure these three latent variables, and the model structure is shown in Fig. 1.

\section{Model Fitting Test}

The main purpose of model evaluation is to measure the consistency between hypothetical model and the observed data. As shown in Table 18, we have examined the fitting degree of the model from six indicators, including CMIN/DF, GFI and $\mathrm{CFI}$.

It can be seen from the fitting results in the Table that all the six indicators of Chi square fitting, CMIN/DF, RMSEA, GFI, CFI and TLI of the fitting index adopted in this research model have reached an optimal level. The results have shown that the model established in this study is well adapted and acceptable, and can basically meet the requirements of research.

\section{Path significance test}

We have used the software AMOS 22.0 to carry out the calculation of the structural equation model on the collected data, and we have analyzed the running results. The path significance test of the model is shown in Table 19.

Judging from the analysis results of the AMOS output, the standardized coefficients of 22 path hypothesis relationships in the theoretical model set up in the research are significant except for negative communication. Our research results have shown that the path relationship in the theoretical model has been verified.

\section{Utility analysis and discussion}

To leverage the path analysis function of the statistical software AMOS 22.0, we have ticked the choice of "analysis of direct utility and indirect utility of variables" to calculate the relationship of utility among various latent variables, and we have sorted out the overall utility table under the standardization of each variable in Table 20. 


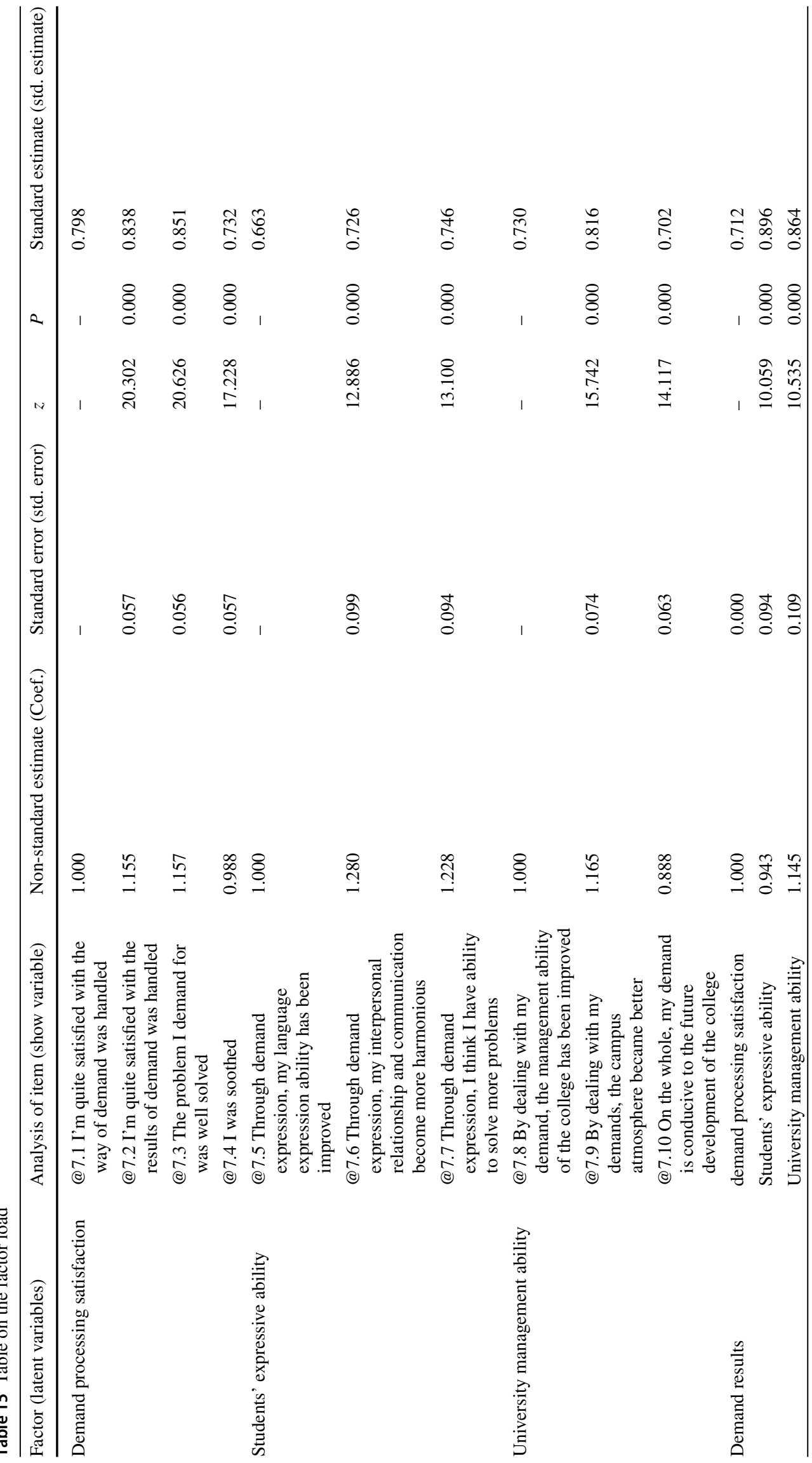


Table 16 AVE and CR index results of the model

\begin{tabular}{lll}
\hline Factor & $\begin{array}{l}\text { Average variance extracted AVE } \\
\text { values }\end{array}$ & Combined reliability CR value \\
\hline Demand processing satisfaction & 0.651 & 0.881 \\
Students' expressive ability & 0.512 & 0.757 \\
University management ability & 0.570 & 0.797 \\
\hline
\end{tabular}

Table 17 Discriminant validity: Pearson correlation with AVE square root value

\begin{tabular}{llll}
\hline & $\begin{array}{l}\text { Demand processing } \\
\text { satisfaction }\end{array}$ & $\begin{array}{l}\text { Students' expressive } \\
\text { ability }\end{array}$ & $\begin{array}{l}\text { University management } \\
\text { ability }\end{array}$ \\
\hline $\begin{array}{l}\text { Demand processing } \\
\text { satisfaction }\end{array}$ & 0.807 & & \\
$\begin{array}{l}\text { Students' expressive } \\
\text { ability }\end{array}$ & 0.518 & 0.716 & 0.755 \\
$\begin{array}{l}\text { University management } \\
\text { ability }\end{array}$ & 0.515 & 0.604 & \\
\hline $\begin{array}{l}\text { The diagonal digit is the AVE square root value } \\
\text { The }\end{array}$
\end{tabular}

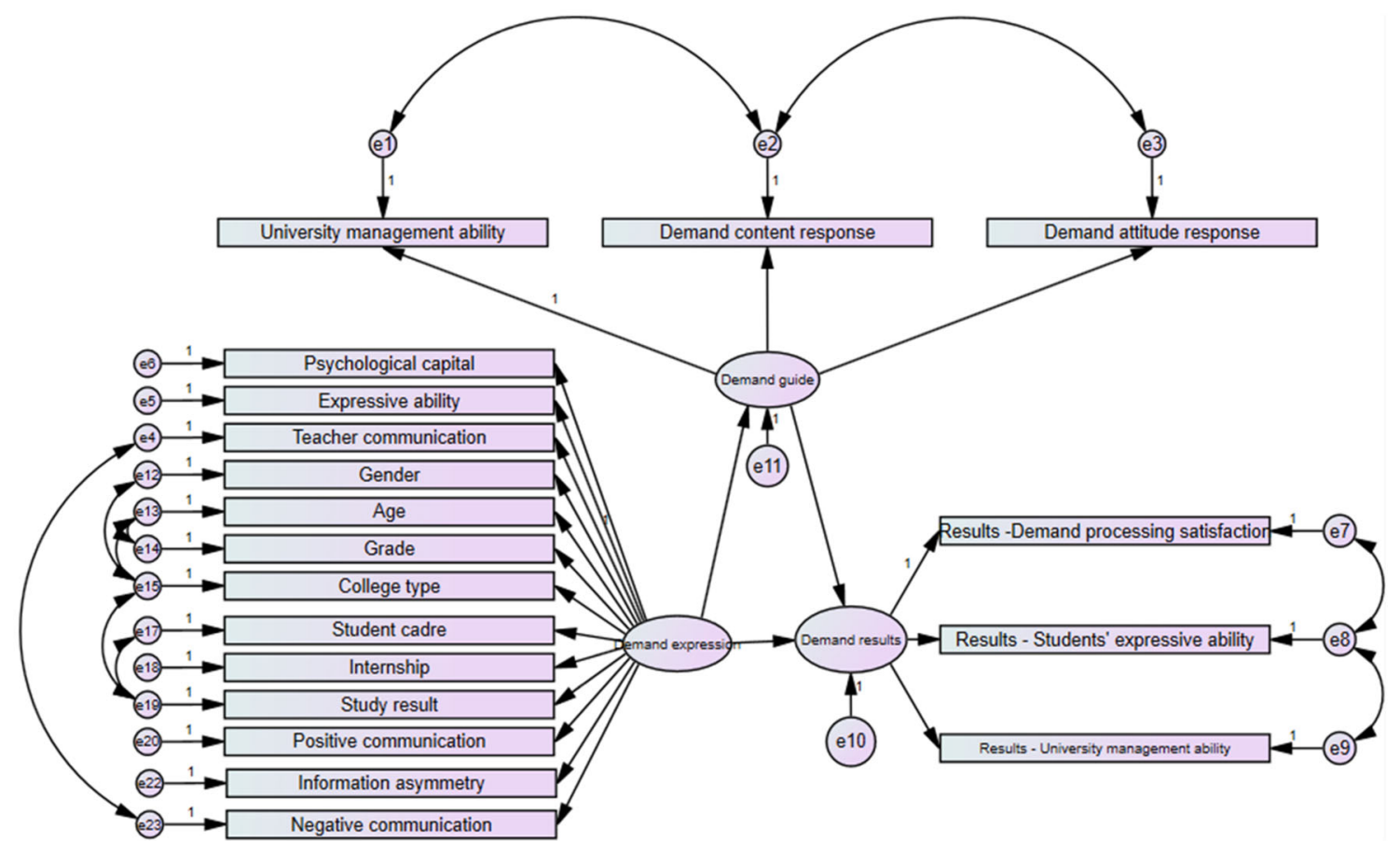

Fig. 1 Diagram on the structural equation model

We have used the software AMOS 22.0 to sort out results of the direct utility of various variables, and the statistical results are shown in Table 21.

1. The direct impact of demand expression on demand guidance amounts to 0.694 , indicating that the improvement of the tendency of demand expression can help enhance the demand guidance.

2. The direct impact of demand expression on the result of demand handling amounts to -0.221 , indicating that the improvement of the tendency of demand expression will undermine the results of demand handling.

3. The direct impact of demand guidance on the result of demand handling amounts to 1.260 , indicating that the improvement of the performance of demand guidance can significantly enhance the results of demand handling.

In other words, when the students have improved the tendency of expressing their demands, the needs arisen from the demand guidance will increase. However, the performance of the demand handling becomes worse. If we can improve 
Table 18 Results of model fitting

Table 19 Path significance test

\begin{tabular}{lllc}
\hline Fitness test index & The ideal standard & The model results & Conclusion \\
\hline Chi-square $\left(X^{2}\right)$ & Non-significant & 0.338 & $\sqrt{ }$ \\
Normed Chi-square(CMIN/DF) & $<5.0$ & 4.480 & $\sqrt{ }$ \\
RMSEA & $<0.08$ & 0.020 & $\sqrt{ }$ \\
GFI & $>0.8$ & 0.888 & $\sqrt{ }$ \\
CFI & $>0.8$ & 0.867 & $\sqrt{ }$ \\
TLI & $>0.8$ & 0.836 & $\sqrt{ }$ \\
\hline
\end{tabular}

\begin{tabular}{lrrrrr}
\hline & Estimate & S.E & C.R & $P$ & Label \\
\hline Demand guide $\leftarrow$ Demand expression & 1.010 & 0.097 & 10.467 & $* * *$ & 0.694 \\
Demand result $\leftarrow$ Demand expression & -0.409 & 0.115 & -3.554 & $* * *$ & -0.221 \\
Demand result $\leftarrow$ Demand guide & 1.601 & 0.100 & 16.002 & $* * *$ & 1.26 \\
University management ability $\leftarrow$ Demand guide & 1.000 & & & & 0.82 \\
Demand content response $\leftarrow$ Demand guide & 0.980 & 0.059 & 16.669 & $* * *$ & 0.695 \\
Demand attitude response $\leftarrow$ Demand guide & 1.270 & 0.058 & 21.975 & $* * *$ & 0.817 \\
Teacher communication $\leftarrow$ Demand expression & 1.000 & & & & 0.55 \\
Expressive ability $\leftarrow$ Demand expression & 1.509 & 0.124 & 12.145 & $* * *$ & 0.762 \\
Psychological capital $\leftarrow$ Demand expression & 1.392 & 0.106 & 13.103 & $* * *$ & 0.921 \\
Results - demand processing satisfaction $\leftarrow$ Demand result & 1.000 & & & & 0.834 \\
Results-students' expressive ability $\leftarrow$ Demand result & 0.611 & 0.041 & 14.871 & $* * *$ & 0.579 \\
Results-university management ability $\leftarrow$ Demand result & 0.695 & 0.044 & 15.629 & $* * *$ & 0.618 \\
Gender $\leftarrow$ Demand expression & -0.137 & 0.060 & -2.296 & 0.022 & -0.109 \\
Age $\leftarrow$ Demand expression & 0.136 & 0.062 & 2.187 & 0.029 & 0.103 \\
Grade $\leftarrow$ Demand expression & -0.317 & 0.165 & -1.922 & 0.055 & -0.091 \\
College type $\leftarrow$ Demand expression & -0.582 & 0.132 & -4.405 & $* * *$ & -0.213 \\
Student cadres $\leftarrow$ Demand expression & -0.300 & 0.060 & -5.017 & $* * *$ & -0.245 \\
Internship $\leftarrow$ Demand expression & -0.181 & 0.053 & -3.394 & $* * *$ & -0.162 \\
Study result $\leftarrow$ Demand expression & -0.561 & 0.128 & -4.376 & $* * *$ & -0.212 \\
Positive communication $\leftarrow$ Demand expression & 1.279 & 0.114 & 11.253 & $* * *$ & 0.669 \\
Information asymmetry $\leftarrow$ Demand expression & 1.025 & 0.104 & 9.843 & $* * *$ & 0.548 \\
Negative communication $\leftarrow$ Demand expression & -0.022 & 0.128 & -0.170 & 0.865 & -0.008 \\
\hline
\end{tabular}

the performance of the demand guidance, we will be able to further enhance the performance of the demand handling.

The results of indirect utility of each variable are shown in Table 22.

The expression of demands imposes an indirect impact on the demand guidance, which amounts to 0.874 . The utility of indirect impact amounts to $0.778,0.730$ and 1.051, respectively.

We have used the bootstrap function of the software AMOS 22.0 to set the number of bootstrap samples to 2000, and we have set the percentage confidence intervals to $95 \%$. In addition, we have adopted the method of maximum likelihood estimation. In case the bootstrapping falls within the range of $95 \%$ confidence interval and its estimation interval does not contain zero under the condition of significance, then we shall reject the assumption that the utility does not exist.
In other words, the hypothesis of utility existence is verified. Table 23 shows the following intermediary variables.

According to the report form of intermediary variables, we can conclude that the indirect impact of the three intermediary channels are significant, namely, expression of demands $\rightarrow$ guidance of demands $\rightarrow$ the university's management capabilities; Expression of demands $\rightarrow$ guidance of demands $\rightarrow$ students' expression ability; Expression of demands $\rightarrow$ guidance of demands $\rightarrow$ satisfaction about the handling of demands. The results have shown that the three intermediary impacts are all verified. 
Table 20 Standardized overall utility among variables

\begin{tabular}{|c|c|c|c|}
\hline & Demand expression & Demand guide & Demand result \\
\hline Demand guide & 0.694 & 0.000 & 0.000 \\
\hline Demand result & 0.653 & 1.260 & 0.000 \\
\hline Negative communication & -0.008 & 0.000 & 0.000 \\
\hline Information asymmetry & 0.548 & 0.000 & 0.000 \\
\hline Positive communication & 0.669 & 0.000 & 0.000 \\
\hline @ 19.Study result & -0.212 & 0.000 & 0.000 \\
\hline @ 18.Whether have internship experience & -0.162 & 0.000 & 0.000 \\
\hline @ 17.Whether to serve as student cadre during the period of college & -0.245 & 0.000 & 0.000 \\
\hline @ 15.College type & -0.213 & 0.000 & 0.000 \\
\hline @ 14.Grade & -0.091 & 0.000 & 0.000 \\
\hline @ 13.Age & 0.103 & 0.000 & 0.000 \\
\hline @12.Gender & -0.109 & 0.000 & 0.000 \\
\hline Results-university management ability & 0.404 & 0.778 & 0.618 \\
\hline Results-students' expressive ability & 0.379 & 0.730 & 0.579 \\
\hline Results-demand processing satisfaction & 0.545 & 1.051 & 0.834 \\
\hline Normal self-cognition & 0.921 & 0.000 & 0.000 \\
\hline Expressive ability & 0.762 & 0.000 & 0.000 \\
\hline Teacher communication & 0.550 & 0.000 & 0.000 \\
\hline Demand attitude response & 0.567 & 0.817 & 0.000 \\
\hline Demand content response & 0.482 & 0.695 & 0.000 \\
\hline University management ability & 0.569 & 0.820 & 0.000 \\
\hline
\end{tabular}

Table 21 Standardized utility of direct impact among variables

\begin{tabular}{|c|c|c|c|}
\hline & Demand expression & Demand guide & Demand result \\
\hline Demand guide & 0.694 & 0.000 & 0.000 \\
\hline Demand result & -0.221 & 1.260 & 0.000 \\
\hline Negative communication & -0.008 & 0.000 & 0.000 \\
\hline Information asymmetry & 0.548 & 0.000 & 0.000 \\
\hline Positive communication & 0.669 & 0.000 & 0.000 \\
\hline @ 19.Study result & -0.212 & 0.000 & 0.000 \\
\hline @ 18. Whether have internship experience & -0.162 & 0.000 & 0.000 \\
\hline @ 17. Whether to serve as student cadre During the period of college & -0.245 & 0.000 & 0.000 \\
\hline @ 15.College type & -0.213 & 0.000 & 0.000 \\
\hline @14.Grade & -0.091 & 0.000 & 0.000 \\
\hline @ 13.Age & 0.103 & 0.000 & 0.000 \\
\hline @ 12.Gender & -0.109 & 0.000 & 0.000 \\
\hline Results-university management ability & 0.000 & 0.000 & 0.618 \\
\hline Results-Students' expressive ability & 0.000 & 0.000 & 0.579 \\
\hline Results-demand processing satisfaction & 0.000 & 0.000 & 0.834 \\
\hline Normal self cognition & 0.921 & 0.000 & 0.000 \\
\hline Expressive ability & 0.762 & 0.000 & 0.000 \\
\hline Teacher communication & 0.550 & 0.000 & 0.000 \\
\hline Demand attitude response & 0.000 & 0.817 & 0.000 \\
\hline Demand content response & 0.000 & 0.695 & 0.000 \\
\hline University management ability & 0.000 & 0.820 & 0.000 \\
\hline
\end{tabular}




\section{Policy recommendations}

Through the establishment of the multi-dimensional model on the expression and guidance of demands, we can not only answer the questions mentioned above, but also provide theoretical support by setting up a model to improve the management service of the university, the communication and expression ability of college students, and the college students' level of satisfaction about the demand handling, so as to build a harmonious campus. Policy recommendations are hereby provided.

\section{Improving students' ability of proactive communication and expression is helpful to guide and address the demands}

Judging from the above data analysis, we can see that such factors as the proactive communication, information asymmetry, mentors' communication fluency, students' communication and expression ability and psychological capital may impose a positive impact on the expression of demands. Specifically, the standardized regression coefficient $\beta$ of proactive communication amounts $0.669, P<0.001$. The more proactive the students' communication skills are, the more likely they will adopt the form of demand expression. The standardized regression coefficient $\beta$ of the level of information asymmetry amounts to $0.548, P<0.001$. The higher the level of information asymmetry between students and senior teachers during communication and expression, the more likely students will resort to the expression of demands. The standardized regression coefficient $\beta$ of communication fluency with teachers amounts to $0.550, P<0.001$, indicating that the more fluent the communication between students and teachers, the more likely students will resort to the form of demand communication. The standardized regression coefficient $\beta$ of students' communication and expression ability amounts to $0.762, P<0.001$, and the stronger the students' communication and expression ability, the more inclined they are to adopt the form of demand expression. The standardized regression coefficient $\beta$ of psychological capital amounts to $0.921, P<0.001$, indicating that the more proactive the students are to their own cognition and the higher their psychological capital, the more likely they are to adopt the method of demand expression to communicate their demands. To some extent, these results have shown that the expression of demands may not be simply venting out negative emotions or resorting to irrational behavior of students, but a proactive method to cope with the issues and express students' wishes. If properly guided, the demand expression can play an optimal role in improving students' mental health, safeguarding the rights and interests of both the students and the university, and ensuring efficient operation and coordination of the joint handling of demands.
Establishment of an efficient mechanism of demand guidance helps to improve the level of management of the university

Judging from the above statistical analysis, the expression of demands can have a positive impact on the demand guidance, and the standardized regression coefficient $\beta$ amounts to $0.694, P<0.001$, indicating that the stronger the tendency of demand expression, the stronger needs for corresponding demand guidance [9]. Specifically, whether it is response to content, response to attitude or management level of the university, the greater the intensity that students raise demands online, the more positive the university will guide the demands. Among them, the corresponding standardized regression coefficient $\beta$ of the subjects of demands amounts to $0.695, P<0.001$. That is to say, every unit of demand expression is increased by 0.695 units during the demand guidance. The corresponding standardized regression coefficient $\beta$ of demand attitude amounts to $0.817, P<0.001$. That is to say, every unit of demand expression is increased by 0.817 units during demand guidance. The standardized regression coefficient $\beta$ of the university's management level amounts to $0.820, P<0.001$. That is to say, every time the demand expression is increased by 1 unit, the level of management service of the university will be improved by 0.820 units. Students who resort to the formal and informal online platform raise a large number of demands [10]. Therefore, the university shall be able to establish an efficient mechanism on demand guidance and a reasonable way of resolving and handling demands, and to timely and effectively provide feedback. Only by doing so can we make students satisfied and improve the management level of universities, so as to build a harmonious campus.

\section{Actively establish a virtuous circle between the expression of students' demands and the satisfaction of the demand handling}

When students have a high level of satisfaction about the results of the demand handling, there will also be more students who can improve their expression ability, and the university can also enhance its own management capabilities. The standardized regression coefficient $\beta$ of satisfaction about demand handling amounts to $0.834, P<0.001$; the standardized regression coefficient $\beta$ of improving students' expression ability amounts to $0.579, P<0.001$; And the standardized regression coefficient $\beta$ of enhancing the university's management capabilities amounts to $0.618, P$ $<0.001$. However, the expression of demands may impose a negative impact on the results of demand handling. The standardized regression coefficient $\beta$ of the impact amounts to $-0.221, P<0.001$. These results have highlighted the importance of communication and expression of students' 
Table 22 Standardized utility of indirect impact among variables

\begin{tabular}{|c|c|c|c|}
\hline & Demand expression & Demand guide & Demand result \\
\hline Demand guide & 0.000 & 0.000 & 0.000 \\
\hline Demand result & 0.874 & 0.000 & 0.000 \\
\hline Negative communication & 0.000 & 0.000 & 0.000 \\
\hline Information asymmetry & 0.000 & 0.000 & 0.000 \\
\hline Positive communication & 0.000 & 0.000 & 0.000 \\
\hline @ 19.Study result & 0.000 & 0.000 & 0.000 \\
\hline @ 18.Whether have internship experience & 0.000 & 0.000 & 0.000 \\
\hline @ 17.Whether to serve as student cadre during the period of college & 0.000 & 0.000 & 0.000 \\
\hline @ 15.College type & 0.000 & 0.000 & 0.000 \\
\hline @ 14.Grade & 0.000 & 0.000 & 0.000 \\
\hline @ 13.Age & 0.000 & 0.000 & 0.000 \\
\hline @ 12.Gender & 0.000 & 0.000 & 0.000 \\
\hline Results-university management ability & 0.404 & 0.778 & 0.000 \\
\hline Results-students' expressive ability & 0.379 & 0.730 & 0.000 \\
\hline Results-demand processing satisfaction & 0.545 & 1.051 & 0.000 \\
\hline Normal self-cognition & 0.000 & 0.000 & 0.000 \\
\hline Expressive ability & 0.000 & 0.000 & 0.000 \\
\hline Teacher communication & 0.000 & 0.000 & 0.000 \\
\hline Demand attitude response & 0.567 & 0.000 & 0.000 \\
\hline Demand content response & 0.482 & 0.000 & 0.000 \\
\hline University management ability & 0.569 & 0.000 & 0.000 \\
\hline
\end{tabular}

Table 23 Report on the intermediary variables

\begin{tabular}{|c|c|c|c|c|c|}
\hline \multirow[t]{3}{*}{ Mediation path } & \multirow[t]{3}{*}{ Utility values } & \multirow{2}{*}{\multicolumn{2}{|c|}{$\begin{array}{l}\text { Bootstrapping } \\
\text { Bias-corrected } \\
95 \% \text { CI }\end{array}$}} & \multirow[t]{3}{*}{$P$ values (2-tailes) } & \multirow[t]{3}{*}{ Significance test } \\
\hline & & & & & \\
\hline & & Lower & Upper & & \\
\hline Demand expression $\rightarrow$ Demand guide $\rightarrow$ University management ability & 0.778 & 0.658 & 0.916 & 0.001 & Significant \\
\hline $\begin{array}{l}\text { Demand expression } \rightarrow \text { Demand guide } \rightarrow \text { Results—Students' expressive } \\
\text { ability }\end{array}$ & 0.730 & 0.605 & 0.873 & 0.001 & Significant \\
\hline $\begin{array}{l}\text { Demand expression } \rightarrow \text { Demand guide } \rightarrow \text { Demand processing } \\
\text { satisfaction }\end{array}$ & 1.051 & 0.951 & 1.193 & 0.001 & Significant \\
\hline
\end{tabular}

demands. We should not only improve the ability of students' demand expression, but also attach great importance to the guidance of demand expression. The effective guidance of college students' demands will lead to better results of demand handling. Only by properly handling and coping with the method of demand guidance can we improve students' satisfaction about the demand handling. In addition, we will be able to enhance the students' expression ability and the university's capabilities in management service.
Open Access This article is licensed under a Creative Commons Attribution 4.0 International License, which permits use, sharing, adaptation, distribution and reproduction in any medium or format, as long as you give appropriate credit to the original author(s) and the source, provide a link to the Creative Commons licence, and indicate if changes were made. The images or other third party material in this article are included in the article's Creative Commons licence, unless indicated otherwise in a credit line to the material. If material is not included in the article's Creative Commons licence and your intended use is not permitted by statutory regulation or exceeds the permitted use, you will need to obtain permission directly from the copyright holder. To view a copy of this licence, visit http://creativecomm ons.org/licenses/by/4.0/.

\section{Declarations}

\section{Conflict of interest None.}




\section{References}

1. Gheisari M, Najafabadi HE, Alzubi JA, Gao J, Wang G, Abbasi AA, Castiglione A (2021) OBPP: an ontology-based framework for privacy-preserving in IoT-based smart city. Futur Gener Comput Syst 123:1-13

2. Gao J, Wang H, Shen H (2020) Smartly handling renewable energy instability in supporting a cloud datacenter. In: 2020 IEEE international parallel and distributed processing symposium (IPDPS). IEEE, pp 769-778

3. Do DT, Le TA, Nguyen TN, Li X, Rabie KM (2020) Joint impacts of imperfect CSI and imperfect SIC in cognitive radio-assisted NOMA-V2X communications. IEEE Access 8:128629-128645

4. Jiang F, Lin S, Mariano JM (2016) The influence of Chinese college teachers' competence for purpose support on students' purpose development. J Educ Teach 42(5SI):630

5. Pandey PK, Jaboob SSA (2018) A finite difference method for a numerical solution of elliptic boundary value problems. Appl Math Nonlinear Sci 3(1):311-320

6. Shi KB, Tang YY, Liu XZ et al (2017) Secondary delay-partition approach on robust performance analysis for uncertain timevarying Lurie nonlinear control system. Optim Control Appl Methods 38(6):1208-1226

7. Xu X, Li D, Sun M, Yang S, Yu S, Manogaran G, Mavromoustakis CX et al (2019) Research on key technologies of smart campus teaching platform based on $5 \mathrm{G}$ network. IEEE Access 7:20664-20675
8. Guo Z, Tang L, Guo T, Yu K, Alazab M, Shalaginov A (2021) Deep graph neural network-based spammer detection under the perspective of heterogeneous cyberspace. Futur Gener Comput Syst 117:205-218

9. Talay Akyildiz F, Vajravelu K (2018) Galerkin-Chebyshev pseudo spectral method and a split step new approach for a class of two dimensional semi-linear parabolic equations of second order. Appl Math Nonlinear Sci 3(1):255-264

10. Khalid N (2020) Artificial intelligence learning and entrepreneurial performance among university students: evidence from Malaysian higher educational institutions. J Intell Fuzzy Syst 39(4):5417-5435

Publisher's Note Springer Nature remains neutral with regard to jurisdictional claims in published maps and institutional affiliations. 